\title{
Antioxidant Activity of Extract Cantigi (Vaccinium varingiaefolium) (Bl.) Miq and Its Major Compound of GC MS NIST Library Analysis \\ Maratu Soleha ${ }^{1, *}$, Amalia Suleza ${ }^{2}$, Evika Hermiyanti ${ }^{1}$
}

${ }^{1}$ Center of Biomedic and Basic Health Technology, National Institute of Health Research and Development, Ministry of Health, Jakarta, Indonesia

${ }^{2}$ Pharmacy Academy, Ikifa Pharmacy Academy Jakarta, Indonesia

*Corresponding Author.Email: maratu15@yahoo.com

\begin{abstract}
Antioxidant are an important topic in various disciplines especially in the fields of medicine and health. The theory about compounds of radicals, free radicals and antioxidants is growing most diseases are preceded by excessive oxidation reactions in the body. Vaccinium varingiaefolium (Blume) Miq. belongs to Ericaceae family and elucidate its major compound contribute to ease free radicals as an antioxidant effect to human body. The DPPH (2,2-diphenyl-1-pikrilhidrazil) method is one test to determine antioxidant activity. The DPPH method provides information on the reactivity of compounds tested with a stable radical. The spectrum of unknown component was compared with the spectrum of NIST library. The name molecular weight and structure of the component of the test material were as retained. The experiment shows it has moderate anti-oxidant activity, the methanol extract have 15 compounds that have similarity more than $70 \%$ with NIST library whereas 1 compounds formula cannot be detected in databases. There are five major compounds with percentage above $8 \%$. Four compounds mostly in the form of fatty acid methyl ester (FAME) in plant. There are limited data of the of biological activities of those compounds. Some paper said that fatty acid in plant used for biodiesel. One of interesting compound is Dichloroacetic acid (DCA). Latest study shows that DCA have potential in suppressing cell proliferation in cancer cells however some study found its carcinogenic effect.
\end{abstract}

Keywords: antioxidant Cantigi, Vaccinium varingiaefolium (Blume), Miq, GCMS

\section{INTRODUCTION}

This Indonesia has a plenty of endemic plants which spread out over the nation. One of them is Vaccinium varingiaefolium (Blume) Miq. belongs to Ericaceae family. The local name of this plant is Mentigi or Manis Rejo, in different region for example in the West Java this plant famous by the name of purple Cantigi. This endemic plant has a similarity with billberry (V. myrtillus) and blueberry (V. corymbosum). Even this mentigi is to be called "the bilberry of Java" . The group of bilberry and blue berry rich of antioxidant. Cantigi who one of types of bilberry extract may have antioxidant activity. In Java, this plant grows well in the area closed to Sulphur vents or volcano region [1]. Cantigi (Vacinium varingaefolium) (Bl.) Miq) is a plant that grows on the island of Java naturally and only in high agricultural areas above 1,000 above the sea level. This plant is known as a plant that withstands various grips, most of which is information about the origin of typical craters on land [2]. Extract ethanol $70 \%$ of Cantigi stem have analgetic effect on mouse at dose $1200 \mathrm{mg} / \mathrm{kg}$ body weight [3]. At the same dose, it also has anti-inflammatory activity in the mouse, the doze has reduced the plantar induce by carrageenan. The inflammatory test was performed using carrageenan for induction inflammatory effect [4].

Today's antioxidants are an important topic in various disciplines. Especially in the fields of medicine and health, the theory of compounds of radicals, free radicals and antioxidants is growing. This is based on the understanding that most diseases are preceded by excessive oxidation reactions in the body [5]. Cantigi (Vacinium varingaefolium) (B1.) Miq) has 2 color leaves in the apex its color is red to purple while the older leaves color is green. In plant red or purple color may rich of anthocyanin as the flavonoid it may effective for antioxidant.

Cantigi has not been widely studied as a medicinal plant. In this study the methanol extract of the cantigi apex leaves that have red color was examined as the antioxidant activity and the metabolites contained in the extract were examined with GCMS.

\section{METHOD}

Free Radical Damping Method (DPPH)

The DPPH (2,2-diphenyl-1-pikrilhidrazil) method is one test to determine antioxidant activity. The DPPH method provides information on the reactivity of 
compounds tested with a stable radical. So that if DPPH is used as reagent in free radical capture tests it is sufficiently dissolved and will be stable for several years if stored in dry conditions [6]. The cantigi has not been test as an antioxidant. The flavonoid compound in its leaves could have antioxidant effect.

\section{GCMS}

The spectrum of unknown component was compared with the spectrum of NIST library. The name molecular weight and structure of the component of the test material were as retained.

from the leaves of the plant cantigi (Vacinium varingaefolium) (B1.) Miq). Extraction method is done by percolating simplicia which has been dried under the sunlight. The anti-oxidant effect was tested by DPPH immersion method. [6] The principle of DPPH free radical reduction method is the capture of hydrogen by DPPH from antioxidants. Based on the reduction of colored DPPH free radicals by free radical inhibitors which involves measuring the decrease in DPPH absorption at its maximum wavelength, which is comparable to the concentration of free radical inhibitors added to the DPPH solution. This activity is expressed as an effective concentration EC50 or inhibitory concentration IC50, which is the concentration of an antioxidant which can cause $50 \%$

$\%$ inhibition $=$ (absorbance blank - absorbance sample $) \times$ $100 \%$

DPPH to lose the radical character or concentration of an antioxidant which gives a $50 \%$ percent inhibition. [7].

\section{Extraction}

$25 \mathrm{~g}$ of finely ground (100 mesh) and sieved dry reddish dry leaves (simplicial) was dissolved with $12.5 \mathrm{~mL}$ of methanol p.a, put into a closed vessel for at least 3 hours. Filtrate from percolator ware collected in bottle with dripping flow rate $1 \mathrm{~mL}$ per minute after overnight immersion. The concentrated filtrate with rotary evaporator at $60^{\circ} \mathrm{C}$ (Heidolph), Finally using water bath for final concentration process.

Anti Oxidant

The DPPH (2,2-diphenyl-1-pikrilhidrazil) method is one test to determine antioxidant activity. The DPPH method provides information on the reactivity of compounds tested with a stable radical. So that if DPPH is used as reagent in free radical capture tests it is sufficiently dissolved and will be stable for several years if stored in dry conditions. [6]. DPPH provides strong absorption at a wavelength of $515 \mathrm{~nm}$ with dark violet colors. Catching free radicals causes electrons to become pairs which then causes color loss which is proportional to the number of electrons taken [7]. The serial extracts were tested using spectrophotometry Optizen model 5U4708-12606-00. The test steps are as follows:

\section{- Measure the maximum wavelength absorbance of DPPH}

As much as $2 \mathrm{~mL}$ of $0.2 \mathrm{mM}$ DPPH solution were put into the test tube and then added $2 \mathrm{~mL}$ of methanol p.a shake until homogeneous then poured into the insert cuvette into a UV-Vis spectrophotometer with a wavelength of $400-800 \mathrm{~nm}$ [8]

\section{- Blank solution}

A $3 \mathrm{~mL}$ DPPH $0.2 \mathrm{~mL}$ solution was put into a test tube, $3 \mathrm{~mL}$ methanol p.a was added then cover the test tube with aluminum foil, then shaken until homogeneous and measured with a UV-Vis spectrophotometer at wavelength with maximum DPPH absorption [9]

A series of concentrations of 20,40,60, 80 and 100 ppm of methanol extract were made. Each $3 \mathrm{~mL}$ test solution was put into a test tube. Added $3 \mathrm{~mL}$ DPPH $0.2 \mathrm{mM}$ solution, then homogenized then incubated at $37^{\circ} \mathrm{C}$ in a dark room for 30 minutes.

\section{- Vitamin C Comparison Solution}

The concentration of $2,4,6,8,10 \mathrm{ppm}$ was made. each concentration of the vitamin $\mathrm{C}$ comparison solution is $3 \mathrm{~mL}$, homogenized and then incubated at $37^{\circ} \mathrm{C}$ in a dark room for 30 minutes. As much as $5 \mathrm{mg}$ of vitamin $\mathrm{C}$ powder was dissolved with $50 \mathrm{~mL}$ of methanol p.a in a $50 \mathrm{~mL}$ Each concentration of vitamin $\mathrm{C}$ standard on solution as much as $3 \mathrm{~mL}$, homogenized then incubated at $37^{\circ} \mathrm{C}$ in a dark room for 30 minutes. [10]

\section{- IC50 (inhibitory concentration}

The parameters commonly used to interpret the results of the antioxidant activity test using the DPPH method are Inhibition concentration (IC50) or often called IC50 value, which is concentration which causes a 50\% loss of DPPH activity to calculate IC50 values. Percentage of inhibition can be calculated using the following formula;

The sample concentration and percent inhibition obtained were plotted on the $\mathrm{x}$ and $\mathrm{y}$ axes in the linear regression equation, respectively. This equation is used to determine the IC50 value of each sample stating with the value of $y$ of 50 and the value of $x$ to be obtained as IC50.

Table 1. Antioxidant Categories Based On IC50 Value

\begin{tabular}{ll}
\hline Category & Nilai IC50 \\
\hline Very Strong & $<50$ \\
Strong & $50-100$ \\
Moderate & $101-150$ \\
Weak & $151-200$ \\
\hline
\end{tabular}

\section{Major Compounds analysis}

Analysis of extract content was performed on gas chromatography tools Agilent Technologies $6890 \mathrm{~N}$ and Mass Spectrometry Agilent Technology 5975B with MSD detector. The column used by Agilent 19091S-433 32325 C Max HP-5\% Phenyl Methyl Siloxane Capillary $30.0 \mathrm{~m} \times 250 \mu \mathrm{m} \times 0.25 \mu \mathrm{m}$ nominal. Gas carrier $1 \mathrm{~mL}$ per min, Split 10: 1. MSD Software Turbomass Detector 5.2 inject sample: $2 \mu 1$. Oven temperature program $110^{\circ} \mathrm{C}$ up to $200^{\circ} \mathrm{C}$ at the rate of $10^{\circ} \mathrm{C} / \mathrm{min}$-no hold: up to $280^{\circ} \mathrm{C}$ at the rate of $5^{\circ} \mathrm{C} / \mathrm{min} 9 \mathrm{~min}$ hold: Injector temperature $250^{\circ} \mathrm{C}$. Total GC running time $36 \mathrm{~min}$.

\section{MS Program}

Library used NIST Version Year 2005: Inlet line temperature $200^{\circ} \mathrm{C}$. Electron energy $70 \mathrm{eV}$ : Mass Scan $(\mathrm{m} / \mathrm{z}): 45$ 45D : Solvent Delay : 0-2 min: total MS running time $36 \mathrm{~min}$. Interpretation on $\mathrm{GC}$ mass spectrum was conducted using the database of National 
Institute Standard and Technology having more than 62 patterns. The spectrum of unknown component was compared with the spectrum of NIST library. The name molecular weight and structure of the component of the test material were as retained.[11]

\section{RESULTS AND DISCUSSION}

\section{A. Extraction}

Extraction is done by cold method of percolation, this method uses an always new solvent which is repeatedly added and flows through filter paper and flannel, the weight of the sample used is $25 \mathrm{~g}$ of dried leaf simplicia, methanol used in extracting approximately $300 \mathrm{~mL}$ and $250 \mathrm{~mL}$ of yield then concentrated by evaporating the liquid with a rotary evaporator and evaporated in the water bath until a thick extract of 7,524g was obtained, the extraction process took 3 to 4 days. Percent of yield obtained was $30,09 \% \mathrm{~b} / \mathrm{b}$.

\section{B. Anti-oxidant activity}

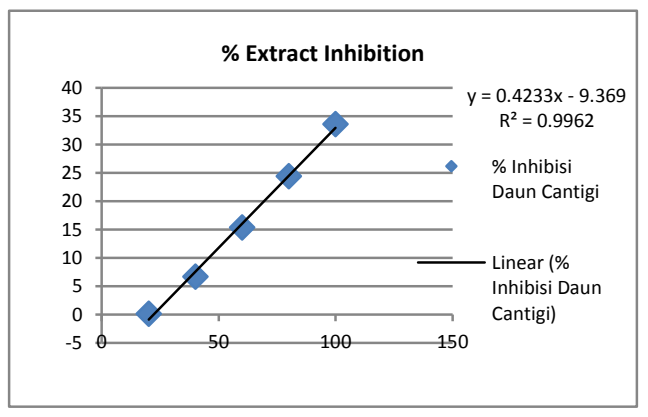

Figure 1. Antioxidant Activity of Vaccinium Varingiaefolium (Blume) Miq

Table 2. Antioxidant of Vaccinium Varingiaefolium (BLUME) Miq

\begin{tabular}{|l|l|}
\hline $\begin{array}{c}\text { Extract Concentration } \\
\text { Cantigi of Leave (ppm) }\end{array}$ & $\begin{array}{l}\text { Antioxidant Activity } \\
\text { (\%) }\end{array}$ \\
\hline 20 & 0,12 \\
\hline 40 & 6,69 \\
\hline 60 & 15,35 \\
\hline 80 & 24,36 \\
\hline 100 & 33,61 \\
\hline
\end{tabular}

Table 3. IC50 Antioxidant of Vaccinium Varingiaefolium (BLUME) Miq

\begin{tabular}{lcc}
\hline Sample & IC50 $(\boldsymbol{\mu g} / \mathbf{m L})$ \\
\hline $\begin{array}{l}\text { Vaccinium } \\
\text { varingiaefolium }\end{array}$ & \multicolumn{1}{c}{141,22} \\
$\begin{array}{l}\text { (Blume) Miq. } \\
\text { Vitamin C } \\
\text { positif) }\end{array}$ & (control 6,97 \\
\hline
\end{tabular}

The amount of antioxidant activity is characterized by the number IC50, which is the concentration of the sample solution needed to inhibit $50 \%$ of DPPH free radicals. The test results showed cantigi leaf extract as an antioxidant with IC50 141,22 $\mu \mathrm{g} / \mathrm{mL}$. IC50 value of cantigi leaf extract is smaller than vitamin c with IC50 value of $6.97 \mu \mathrm{g} / \mathrm{mL}$. This shows that cantigi leaf extract has a moderate category of antioxidant activity which has an IC50 value of less than $150 \mu \mathrm{g} / \mathrm{mL}$ and vitamin c has a strong category of antioxidant activity which has an IC50 value of less than $50 \mu \mathrm{g} / \mathrm{mL}$.

Testing of antioxidant activity at various concentrations showed that higher concentrations showed higher antioxidant activity but when compared to vitamin $\mathrm{C}$ cantigi leaves had lower antioxidant activity. The other study of antioxidant activities if cantigi find that its fruits has strong antioxidant activities. Inhibition concentration of cantigi fruit was $44,994 \mathrm{ppm}$ while this study finding the apex leaves of red to purple of cantigi leaves was $141,22 \mathrm{ppm}$ $(\mathrm{mg} / \mathrm{mL})$. The antioxidant activities in cantigi fruits stronger than its apex leaves. [12]

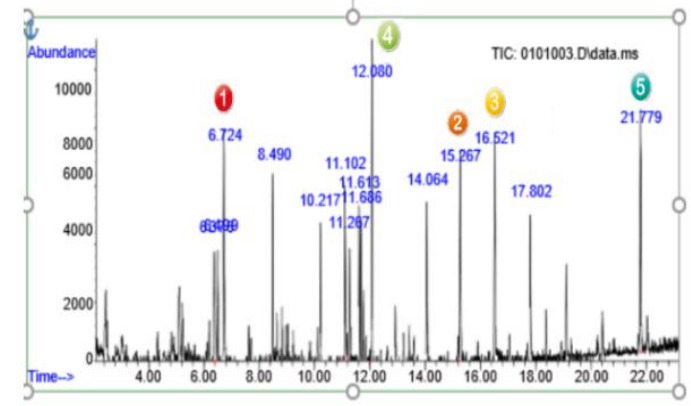

Figure 2. Structure of Cantigi (Vacinium Varingaefolium) (B1.) Miq) Methanol Extract

1 Dodecanoic acid methyl ester

2 Nonadecane

3 Hydroxylamine o-decyl

4 S-[N-[Adamantyl]amidino]methyl hydrogen thiosulfate

5 Dichloroacetic acid decyl ester

From methanol crude extract analysis with GC MS appear 15 peaks pattern represent of 15 compounds. There are 5 compounds major peak that have similarity more than $70 \%$ compare with NIST library. The 4 Highest figure profile as follow:

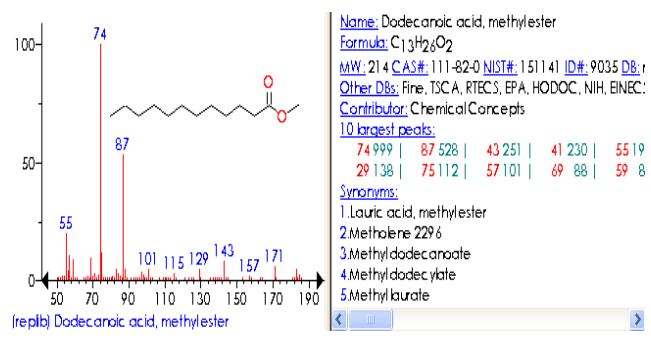

Figure 3. Dodecanoic Acid Methyl Esther Cromatogram

Each molecule has the same fragmentation properties with the same ionization conditions. Patterns in the 
spectrum are compared with patterns in the NIST library. Dodecanoic acid methyl Esther fragmentation spectra have similarities with 5 other molecules namely lauric acid methyl ester, Methylene, Methyldodecylate, Methyllaurate. The most stable fragment of all has 74 mw.

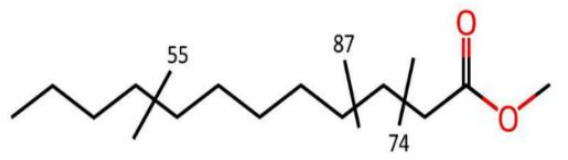

Figure 4. Dodecanoic Acid Methyl Esther Fragmentation Sites

The fragmentation of Dodecanoic acid methyl Esther shown in figure 4. Two fragmentation near functional group and the one was at the hydrocarbon tail. There are three fragmentation with the molecular size 55, 87 and 74 . The mass were match with the fragmentation site in the figure above.

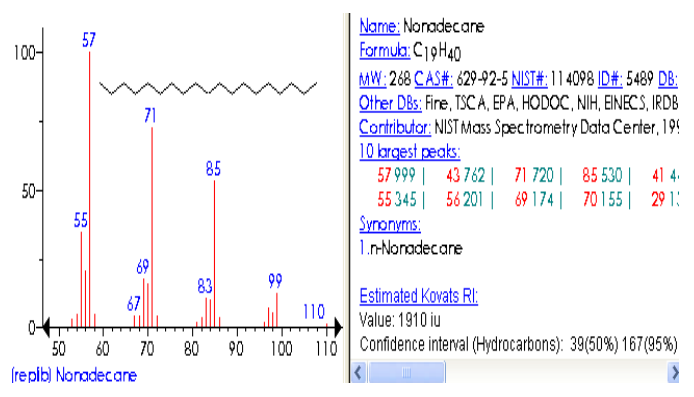

Figure 5. Nonadecane Chromatogram

In the nonadecane fragmentation pattern the most stable compound at $57 \mathrm{~m} / \mathrm{z}$. Nonadecane is a series of hydrocarbon molecules weighing $268 \mathrm{~m} / \mathrm{z}$. Nonadecane not appear as the intact molecule probably due to degradation during mass spectrum fragmentation.

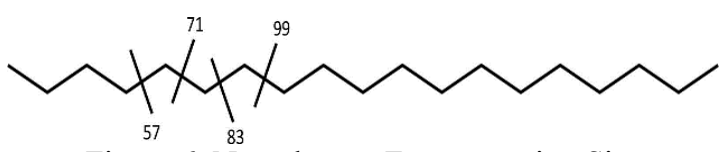

Figure 6. Nonadecane Fragmentation Sites

Nonadecane as hidrocarbon render to fragmentation. Many fragmentaion happeneed in the edge of hidrocarbon chain.

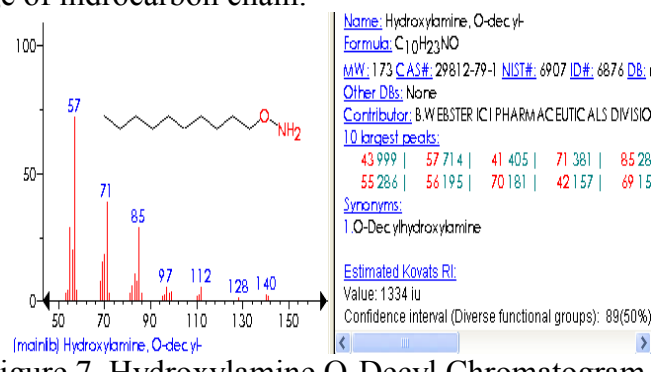

Figure 7. Hydroxylamine O-Decyl Chromatogram

Hydroxylamine o-decyl is a hydrocarbon that has an amine group with 10 carbon chains. The most stable fragmentation fragmentation pattern has molecular weight 57.

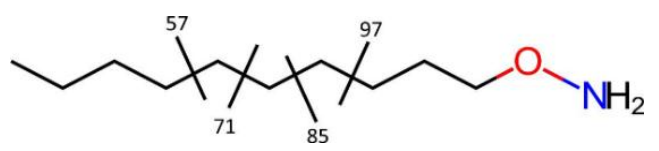

Figure 8. Hydroxylamine O-Decyl Fragmentation Sites

The most fragile bond were hidrocarbon in Hydroxylamine o-decyl stucture. Many fragmentation of hidrocarbon structure locate in the middle of metabolit.

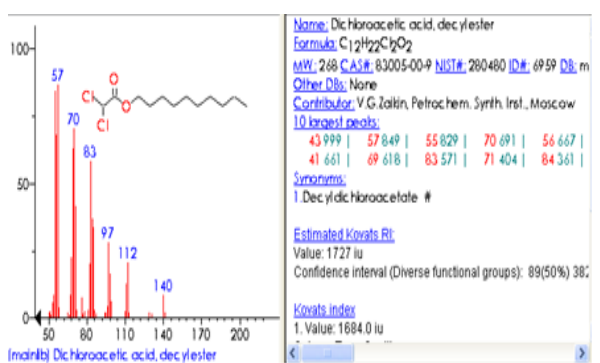

Figure 9. Dichloroacetic Acid Decyl Ester Chromatogram

Dichloroacetic acid decyl ester is synonymous with decyl chloroacetate with a molecular weight of $268 \mathrm{~m}$ / $\mathrm{z}$ having 2 chlorine groups in the ester functional group. The most stabile fragmentation patterns have molecular weight 57.

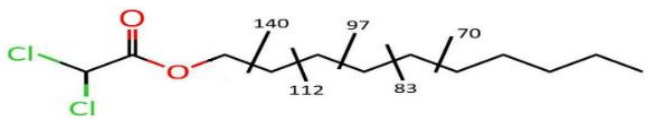

Figure 10. Dichloroacetic Acid Decyl Ester Fragmentation Sites

\section{DISCUSSION}

Table 4. The Five Compound Highest Peak

\begin{tabular}{|c|c|c|c|c|}
\hline $\begin{array}{l}\mathbf{N} \\
\mathbf{0}\end{array}$ & Name & Formula & $\begin{array}{l}\text { Qu } \\
\text { al }\end{array}$ & $\begin{array}{l}\% \\
\text { Ma } \\
\text { x }\end{array}$ \\
\hline 1 & $\begin{array}{l}\text { Dodecanoic acid } \\
\text { methyl ester }\end{array}$ & $\mathrm{C} 13 \mathrm{H} 26 \mathrm{O} 2$ & 83 & 8.98 \\
\hline 2 & Nonadecane & $\mathrm{C} 19 \mathrm{H} 40$ & 72 & 9.87 \\
\hline 3 & $\begin{array}{l}\text { Hydroxylamine } \\
\text { o-decyl }\end{array}$ & $\begin{array}{l}\mathrm{C} 10 \mathrm{H} 23 \mathrm{~N} \\
\mathrm{O}\end{array}$ & 47 & 9.87 \\
\hline 4 & $\begin{array}{l}\text { S-[N- } \\
\text { [Adamantyl]ami } \\
\text { dino] methyl } \\
\text { hydrogen } \\
\text { thiosulfate }\end{array}$ & Undetected & 71 & $\begin{array}{l}10.8 \\
3\end{array}$ \\
\hline 5 & $\begin{array}{l}\text { Dichloroacetic } \\
\text { acid decyl ester }\end{array}$ & $\begin{array}{l}\mathrm{C} 12 \mathrm{H} 22 \mathrm{Cl} \\
2 \mathrm{O} 2\end{array}$ & 35 & $\begin{array}{l}11.8 \\
6\end{array}$ \\
\hline
\end{tabular}

The previous research shows that cantigi fruits has strong anti-oxidant activities[14]. The compound in table 4 were mostly in form of fatty acid methyl ester (FAME) in plant. There are limited data of the of biological activities of those compounds. Some paper said that fatty acid in plant used for biodiesel. 
Varingiaefolium) Terhadap Tebal Plantar Mencit Yang Diinduksi Karagenan. Universitas Jember digital repositori, neuroblastoma growth [13]. Dichloroacetic acid (DCA) reverses reprogramming in tumor cells switch cytoplasmic glucose metabolism to mitochondrial oxidative phosphorylation.

Various concentrations of DCA on A2780 cells resulted in decreased expression of UCP2, a metabolic switch from glycolysis to mitochondrial. [14]. DCA upregulated the expression of activating transcription factor 3 (ATF3) $(\mathrm{p}<0.001)$ in cervical cancer cells. Overexpression ATF3 suppress cell proliferation and induced apoptosis $(\mathrm{p}<0.001)$, the mechanism of DCA suggesting that tumor suppressor protein 53 (P53) was responsible for ATF3-mediated anti-tumorigenesis in DCA-treated cervical cancer [15].

One of Cancer cells suppressive factor through selective elevation of intracellular reactive oxygen species (ROS). Liposomal formulation of dichloroacetic acid (DCA) and metal-organic framework (MOF)- Fe2+ (MD@Lip) can efficiently stimulate ROS- mediated cancer cell apoptosis in vitro and in vivo [16]. However early-life exposure to DCA may be as carcinogenic as life-long exposures, potentially via epigenetic-mediated effects related to cellular metabolism [17].

\section{CONCLUSION}

Vaccinium varingiaefolium (Blume) Miq apex has moderate antioxidant effect and potential as tumor suppressor. The anti-oxidant in the fruits stronger than in the apex of reddish cantigi leaves.

\section{ACKNOWLEDGMENT}

Main contributor Maratu Soleha, member contributor Amalia Suleza, Evika Hermiyanti. Acknowledgment to Center of Biomedic and Basic Health Technology and Ikifa Pharmacy Academy for supporting of this research. Acknowledgment to Uud Nourma Reswandaru, Novi Sulistyaningrum in helping massspectrophotometry analysis.

\section{REFERENCES}

[1] NC. Devi, S. Aminah, and H. Taufikurahman. Ecological aspects of vaccinium varingiaefolium growing in a stressed volcanic environment in Presented in Botany Conference. Bandung: ITB;2001: 34-35.

[2] Reasa, Rusli Niftar Faris. Inventarisasi Tanaman Mentigi Gunung (Vaccinium Varingiaefolium (Bl) Miq) Di Blok Mentigen Kawasan Taman Nasional Bromo Tengger Semeru. Bachelors Degree (S1) thesis. Malang : University of Muhammadiyah Malang;2018.

[3] Fajriani, Zulfiah Nur. Uji aktivitas analgesik dan skrining fitokimia ekstrak etanol $70 \%$ batang mentigi (Vaccinium varingiaefolium). Tesis Universitas Jember 2017. http:// repository.unej.ac.id/handle/123456789/82659.

[4] Yuniar, Wilda, Pengaruh Pemberian Ekstrak Etanol 70\% Batang Mentigi (Vaccinium http://repository.unej.ac.id/handle/123456789/85 183.

[5] Sayuti K., Yenrina R. Antioksidan, Alami dan Sintetik. Padang : Andalas University Press; 2015, h 12-75.

[6] Amelia, P. Isolasi, Elusidasi Struktur dan Uji Aktivitas Antioksidan Senyawa Kimia Dari Daun Garcinia Benthami Pierre (tesis). Depok : Universitas Indonesia; 2011 h.37-45.

[7] Molyneux P. He Use Of The Stable Free Radical diphenylpicryl hydrazyl (DPPH) For Estimating Antixidant Activity. Songklanakarin Journal Science and Technology ; 2004, h 211-219.

[8] Jun MHY, J Fong X, Wan CS, Yang CT, Ho. Camparison of Antioxidant Activites of Isoflavones form Kudzu Root ( Puerarua labata O). Journal Food Scient Institute of Technologist ; 2003, h 211-212.

[9] Wahdaningsih, S., Setyowati EP, Wahyono, S., Aktivitas Penangkap Radikal Bebas Dari Batang Pakis ( Alstonia glauca). Sm.2011 Majalah Obat Tradisional, 16(3) p 156-160.

[10] Yulika Dian Rahayu. Uji aktivitas Antioksidan Ekstrak Metanol Daun Jamplang Syzygiumcumini (L) Skeels Dengan Metoda Refluxs

[11] V. Narayanamoorthi1, K.Vasantha2, R. C. Rency1 and A. Maruthasalam2 GC MS determination of bioactive components of Peperomia pellucida (L.) Kunth. Bioscience Discovery, 6(2):83-88, July - 2015

[12] Anisa Nur Wulansari. (2018) Alternatif cantigi ungu (Vaccinium varingiaefolium) sebagai Antioksidan alami : review. Farmaka Suplemen Volume 16 Nomor 2

[13] Vella, S. , Conti, M. , Tasso, R., Cancedda, R. and Pagano, A. (2012), Dichloroacetate inhibits neuroblastoma growth by specifically acting against malignant undifferentiated cells. Int. J. Cancer, 130: 1484-1493. doi:10.1002/ijc.26173

[14] L Zhou, L Liu, W Chai, T Zhao, X Jin, X Guo. Dichloroacetic acid upregulates apoptosis of ovarian cancer cells by regulating mitochondrial function. Onco Targets Ther. 2019; 12: 17291739. doi: 10.2147/OTT.S194329

[15] Mutalifu Z, Buranjiang G, Jin H. Activating transcription factor 3 enhances chemosensitivity of dichloroacetic acid via p53 pathway incervical squamous epithelial cancer cells. Tropical Journal of Pharmaceutical Research December 2018; 17 (12): 2393-2398 ISSN: 1596-5996 (print); 1596-9827 (electronic)

[16] Sun, L., Xu, Y., Gao, Y., Huang, X., Feng, S., Chen, J., Wang, X., Guo, L., Li, M., Meng, X., Zhang, J., Ge, J., An, X., Ding, D., Luo, Y., Zhang, Y., Jiang, Q., Ning, X., Synergistic Amplification of Oxidative Stress-Mediated Antitumor Activity via Liposomal Dichloroacetic 
Elias T. Gaillard, Tanya M. Moore, Anthony B.

Acid and MOF- Fe2+. Small 2019, 15, 1901156. https://doi.org/10.1002/smL1.201901156

[17] Charles E. Wood, Susan D. Hester, Brian N. Chorley, Gleta Carswell, Michael H. George, William Ward, Beena Vallanat, Hongzu Ren, Anna Fisher, April D. Lake, Carlin V. Okerberg,
Deangelo, Latent carcinogenicity of early-life exposure to dichloroacetic acid in mice, Carcinogenesis, Volume 36, Issue 7, July 2015, Pages 782-791, 